\title{
The Reading Horizont of Adam Smith from the Perspective of His Italian Library
}

\author{
Sanda-Maria Ardeleanu \\ University Professor DHC \\ Cristina loniță \\ PhD Cand. "Ștefan cel Mare" University of Suceava
}

\begin{abstract}
The paper proposes understanding the reading interest in Italian of the thinker Adam Smith (1723-1790), author of the Theory of Moral Sentiments and of the Wealth of Nations from the perspective of the partial review of his library's catalogue, with approximately 1,000 titles published in English, French, Italian, Greek and Latin. The list of books published in Italian, which Adam Smith purchased for his library and we assume he also read, since he quoted some, represent the Appendix of the present work. From his Italian library, 60 volumes were identified, published between 1547 (B. Castiglione, II Cortegiano) and 1784 (32 volumes from Parnaso Italiano ovvero Raccolto de' Poeti Classici Italiani). Just a few years before his death, the great admiror of Italian literature, assiduous reader of Italian poetry, drama, memoirs, correspondence, biographies, jurisprudence, economics, art and history (especially that of Venice and Florence) was still purchasing and reading books from the Italian states, a fact which sketches a personality with a profound cultural and humanities features.
\end{abstract}

Keywords: Adam Smith, Italian Enlightenment, Italian library, Italian catalogue, Italian publishing, Italian bibliology

\section{Introduction}

Rare and happy are the cases recorded in the European history when the library of an Enlightenment thinker has the catalogue published and can reveal, through its research, the professional and relaxation reading in order to know the man recorded in the universality through the cultural inheritance left to us. The author himself lived to see five editions published of his book The Theory of Moral Sentiments $(1759,1761,1767,1774,1781)$ as well as five editions from his other, more famous work, The Wealth of Nations $(1776,1778,1784,1786,1789)$ translated in Danish, German, French, Italian and Spanish.

The child once kidnapped by the gypsies, who seemed destined to a lower life rank, recovered through a miracle which will lead him, after decades of solitary work and stead-fast work, through his writings, to an amazing gifting of the humanity, will be called, towards the end of his life, at the highest level of the English political level that the whole level has to learn from him. After his death, we also learn from him: from the books given by him we learn to think at more abstract and more generous levels, which open new paths of investigation and how to be better people; from the books he once read, we find the path followed by the Enlightenment thinker in modelling his thoughts, the spiritual models in a period in which the book represented, when mass-media overwhelming us today was missing, the only escape from reality, the reading domains in which he found refuge during his relaxation moments. Lacking the family life, reading, but also maintaining a correspondence, according to the fashion of the period, Adam Smith spent a large part of time. We will have a look upon his readings in order to know better the speciality readings, but also the loisir ones, this time from the Italian books' catalogue.

Those knowing the life and work of the Scottish Adam Smith (1723-1790), today recognise him unanimously as the founder of the modern political economy and they know that more than 200 years from his death, after the cult of his work spread everywhere in Europe, the two fundamental titles knowing numerous editions in various languages, - in 1894, it was 
published the reconstructed catalogue of the Adam Smith's library, ${ }^{1}$ which, without being full ${ }^{2}$ („this catalogue includes a great part of library of Adam Smith", p. VIII), comprises a great part of the books held by the philosopher. The volume comprises 6 chapters: I. History of the library, with a letter of Adam Smith dated April $4^{\text {th }} 1760$, II. List of works, III. Adam Smith's will, IV. The portraits of Adam Smith, V. Adam Smith on Portrait Painting, VI. Analysis of the library and list of contributors to the catalogue; Catalogue and Index.

In the 30 introductory pages of the general catalogue, it is made the observation that, in the will drafted in 1776 , thus with approximately 15 years before his death, the owner decided the fate his precious library. Within the next hundred years, the books were divided among the legal heirs, and part of the library was lost. In order to reconstruct and for the purpose of publishing, the editor of the catalogue appealed to the contributors' help, whose list we find before the catalogue itself. The mysterious initial we see in the catalogue of Adam Smith's library, on the right-hand side column, belongs to the contributor who toiled in order to recover from which we benefit today. As a true instrument of the modern working, which this Catalogue of... desires to be, it was endowed at the end with an Index of the names of the persons found in the Introduction (Index to the Introduction and the Principles Names not registered alphabetically in the catalogue).

The current period of the audio-video technology removes the idea of a private library, even that of public library, replacing them with the concept of "electronic library", that is why we find it rather difficult to accept that, during the Enlightenment, a Scottish university professor could have a library comprising between 2,000 and 5,000 volumes ${ }^{3}$. He himself stated to a friend that it is "a small but excellent library", for whose foundation he placed a large effort of selection, since it was created "with a great judgement" considering that "I am a beau in nothing but my books" 4 .

The publisher states that the present catalogue comprises 1,000 recordings and 2,200 titles ${ }^{5}$, by "recording" being understood the author. As methodology to achieve it, he opted for alphabetizing the authors. Within several works by the same author, some were ordered alphabetically, other times according to succession of the publishing years, no matter the publication language of the editing data (locality, year). With regard to the structure of the library ${ }^{6}$, the organiser of the catalogue appreciates that up to a fifth comprised literature and art books, up to a fifth were books by the Greek and Latin classics and of the commentators, and another fifth was represented by the law, politics and geography: „Catalogue shows about $1-5^{\text {th }}$ of the books to be on Literature and Art, $1-5^{\text {th }}$ of Classical (Latin and Greek) authors, or their commentators, and $1-5^{\text {th }}$ on Law, Politics, and Geography. Works on Political Economy and on History are making up another fifth, in nearly equal proportions. Science and Philosophy divide the remaining fifth, if we omit a small group of miscellaneous volumes (chiefly biographical)." (p. XXVIII). Now, when we know in detail the structure of the Scottish professor's library, we can believe the statement of the publisher that „More than a third are in English, a little less than a third in French, and rather less than a quarter in Latin, Italian and Greek, accounting for the remainder in nearly equal proportions. There are three German, all presentation copies, and translations of the author's works. No other languages are represented"7.

Until the present moment of research, we do not know the catalogue to have made the object of an exegesis, neither from the library point of view, the philological approach or of any other nature. The present paper has a documentary foundation the 1894 catalogue, but it was proceeded the extraction of the authors and titles in Italian, without considering the publishing place. The books written by Italian authors, but published in other languages than Italian (i.e. French or English), were set aside. Following these criteria, we drafted the catalogue of books published in Italian from Adam Smith's library, which we are going to discuss below.

Here we introduced the bibliographical details from the general catalogue from 1894, yet we introduced two columns: first for the current number, which identifies the position of the author in the catalogue, used in the statistics carried out, and the

\footnotetext{
${ }^{1}$ A Catalogue of the Library of Adam Smith, author of The Theory of Moral Sentiments and the Wealth of Nations, edited with an introduction by James Bonar, London, Mc Millan, 1894, XXX + $126 \mathrm{p}$.

${ }_{2}^{2}$ „From the nature of the case, the work is incomplete; but perhaps the very publication of this Catalogue may reveal the hiding-place of missing volumes." (Ibidem, p. XXIX)

${ }^{3}$ Ibidem, p. VIII.

${ }^{4}$ Ibidem.

5 lbidem.

${ }^{6}$ Ibidem, p. XXVIII.

${ }^{7}$ Ibidem, p. XXVIII-XXIX.
} 
last column, on the right, in which we introduced the domain typical of the title, giving up the initial of the contributor, whose identification was not useful for the research.

From the beginning it is imposed the observation that the Italian works are included between some editing temporary coordinates: we have three books which draw our attention because of their age:

1) Jacopo Sannanzaro, Arcadia, printed in Venice, in 1524 (position 41, in our catalogue),

2) Conte Baladesar Castiglione, Libro del Cortegiano, Venice, 1547 (position 13),

3) Andrea Palladio, Dell 'architettura, Venice, 1570 (position 33).

These books, of almost 200 years old, are included in the loisir and general culture category, and we do not exclude the possibility to have been an inheritance from his father, since also then, the purchasing of 200 -year old books was a difficult process.

The most recent books in terms of publishing period date back to before the death of the philosopher and appear to be books he personally purchased: Gabriello Chiabrera, Opere, in 6 vol., Venezia, 1782 (position 22) and Abbate Spallanzani, Opuscoli di fisica animale e vegetabile, Modena, 1786 (position 43).

We know that Adam Smith worked until almost the last moment, that he probably read and meditated upon the last books purchased and, when he thought weakened, with just months before his end, he decided to burn many of his papers with the sketches and projects, which today would have signified priceless cultural values ${ }^{1}$.

Let us remember that the maximum intellectual efficiency period of Adam Smith can be placed between 1748, namely the end of his studies, and just 11 years later he will publish The Theory of Moral Sentiments, a book of profound depth, and in 1776, it is published An Inquiry..., following which he publishes nothing else. But that does not mean his intellectual activity ceased: our thinker continued to read, meditate and write, without making known his works. And his last year of creation can be considered the year of his death. We do not know and probably we will never know and we are left only with assuming that the books older than the beginning of the $18^{\text {th }}$ century from his library was partially inherited, partially purchased, since any thinker in training purchases the new elements in his field and copies older than 50-100 years only if he is a passionate reader.

With regard to the domains of interest of the books by the Italian authors, published in Italian, in Italy or abroad, following the creation of the catalogue in the appendix, we proceeded to the identification of the domains which refer to the titles identified and we realised a statistic in Table 1. We did not choose the universal decimal classification, specific of the major libraries, but we proceeded to the alphabetising the domains which were not numerous.

The table shows the following reading interest domains: architecture (1 title), biographies ( 2 titles), law (4 titles), political economy ( 2 titles), philosophy ( 4 titles), history ( 6 titles), literature (30 titles) and sciences ( 3 titles) out of a total of 52 books.

It is self-understood that the discussion regarding the domains in the Italian catalogue can be extended very much, but we will stop only on the reading interest relating to the Italians' history and Italy (position 18 and 25), with special reference to the history of Florence $(1,47)$ and of Venice $(21,40)$. If in the science group, we discover only the work of Galileo Galilei (position 19,20), which gives rise to a certain disappointment, in the philosophy group, the disappointment is easily removed by the quality of the authors: Bentivoglio (political philosophy, position 5), Machiavelli (position 29), Pallavicino (position 34) and the anthology De' pensieri diversi (position 46).

Those knowing the Enlightenment personality of great amplitude know that Adam Smith only in The Theory of Moral Sentiments the author reminds of hundreds of authors whose books he undoubtedly read, although he travelled only in France and Switzerland (Genève, 1764-1766), in order to know Voltaire and discuss with him. He excelled in Greek and Latin, naturally also in French, but not in Italian. However we know he had an extraordinary intuition about the languages, proved by his famous study Considerations concerning the first formation of languages and the different genius of original and compounded languages, which, in the opinion of Eugeniu Coșeriu (1992), contributed to the foundation of a new philological branch, the linguistic typology. We thus have all the reasons to believe that Adam Smith knew Italian at least

${ }^{1}$ Ibidem, p. XIII. 
through the linguistic associations, since he read in Italian, even though there is no proof of studying the language or ever writing in Italian.

In this regard, the Italian catalogue reserves another surprise: a vocabulary recommended by the Academy from Crusca (position 27) for the use of the writers, in order to promote a clean language. We must accept that the publishing date of this Vocabollario (Napoli, 1746) is included in the period of maximum intellectual evolvement of Adam Smith (1748-1789), thus almost surely, while drafting The Theory of Moral Sentiments, at the end of which he added A Dissertation on the origins of languages, known with the title Considerations... already mentioned, yet in the $2^{\text {nd }}$ edition $\left(1761^{1}\right)$ not only did he read it in Italian, but most probably used it as a working instrument.

But the investigation does not stop here. What was Adam Smith reading the most in the literature category? Since the philosopher could not have kept in the house dozens and hundreds of volumes just for furnishing a room. Here we have the absolute amazing surprise: the literature group comprised more than a half of the number of Italian books in the catalogue: 30 out of 52 copies!

The group being broad based, we proceeded to its segmenting on subgroups and Table 2 is as significant as possible: 5 prose books, 2 correspondence books (he himself wrote and received a rich correspondence with the European personalities), 3 theatre books and 30 titles of poetry and poems. This subgroup especially draws the attention: 2-4 poetry volumes by the same author are frequently mentioned, yet others represent true poetry collections. For example, we discover a Metastasio in 12 volumes published in Paris (position 32), a 32-volume collection of Parnaso Italiano ovvero Raccolto de' Poeti Classici Italiani (position 36) and even Zeno, Poesie drammatiche, in 10 volumes (position 52). Resounding names of the Italian poetry cannot be absent: Ariosto, Bojardo, Chiabrera, Dante, Metastasio, Petrarca, Torquato Tasso. Or, the above lead us to the conclusion that Adam Smith often entertained himself reading poetry in Italian, perhaps while having tea with his mother with whom he spent his life.

Regarding the 52 volumes comprising the Italian catalogue of Adam Smith's library, it must be emphasised the absence of the incunabula, the owner of the library being more interested in the printed, relatively new book.

It is imposed to be observed also the presence of an interesting manuscript. It was observed by the publisher of the 1894 catalogue and it was introduced although "that is probably of value"2. On position 49 in the Italian catalogue and on page 117 of the 1894 original, it is mentioned that the manuscript is a parchment, without identification data (i.e. author, title, locality and year), yet the 8 volumes contain the venetian statues, certified by the coat of arms of the city, which shows a certain interest in knowing the city's justice and history. The observation recommends research and remains the task of a specialized bibliologist.

Another method of approaching the Italian catalogue which might be useful in recollecting the main Italian printing centers during the $16^{\text {th }}$ and $17^{\text {th }}$ centuries is represented by the publishing place.

We thus discover books with Italian authors printed in Italian both in Italy and abroad. Among the external printing centres, we enlist:

Parigi (Paris) - 4 copies printed between 1746 and 1768;

Amsterdam in 1666;

London in 1755, 1768, with the version Londra in 1724 și 1768;

Colonia (Koln) in 1646, 1675, 1721;

Glasguae in 1763;

Geneva in 1629.

Three other books were printed in Firenze, one in Rome (1672), Livorno (1771, 1772), Verona (1726), Bologna (1647, 1656), Padova (1766) and Venice, the most important printing centre, with 12 copies and the manuscript "without value" in

\footnotetext{
${ }^{1}$ A Catalogue..., op. cit., p. XI and note 3.

2 Ibidem, p. IX.
} 
8 volumes mentioned above.

Naturally as in any scientific investigation neither the establishment of the Italian catalogue of Adam Smith's library, with the above discussions cannot be considered concluded. Numerous possibilities of approach and the bibliogical surprises can be revealed in this catalogue, but also from the catalogues extracted from the original catalogue and investigated for other languages, authors or domains.

The present paper leads us to some important conclusions regarding the personality of the modern political economy. Although he did not travel in Italy and since we do not know he studied and wrote in Italian, following this investigation, almost surely Adam Smith read in this language, had knowledge of the Italian culture, was willing to appropriate more knowledge about the Italian history, especially that of Florence and Venice, about the justice of the Italian states, architecture, science, but especially its literature. The impressive number of poems and poetry by Italian writers in Italian shows not only the vast and diversified reading interest, but also the sensible and introverted feature, less open towards people and more towards knowledge.

\section{Catalogue of the books by the Italian authors in Italian in the Adam Smith's library}

\begin{tabular}{|c|c|c|}
\hline AUTHOR & TITLE & DOMAIN \\
\hline Ammirato (Scipione) & History Fiorentine. 3 vols. Small fol. vellum. Firenze, 1641. & History of Florence \\
\hline Ariosto (Ludovico) & Comedie. Minim. 4to, calf. Firenze, 1724. & Theatre \\
\hline & Orlando Furioso. 4 vols. 12mo, calf. Parigi, 1746. & Poetry \\
\hline Bellori (Giov. Pietro) & $\begin{array}{l}\text { Le Vite de'Pittori, Scultori, ed Architetti Moderni. I vol. 4to, calf. } \\
\text { Roma, } 1672 .\end{array}$ & Biography \\
\hline Bentivoglio [Cardinal] (Guido) & Relazioni. Fol. calf. Anversa (Antwerp), 1629. & Philosophy \\
\hline & Raccolta di Lettere. 12mo, calf. Colonia, 1646. & Correspondence \\
\hline Boccaccio & Decamerone. Small 4to. 2 vols. N.D. & Prose \\
\hline Boccalini (Trajano) & De' Ragguagli di Parnaso. Minimo, vellum, Amsterdam, 1669. & Prose \\
\hline Bojardo (Matteo Maria) & Orlando Innamorato. 1 vol. 4to. Venetia, 1609. & Poetry \\
\hline & The same. 4 vols. 12mo, tree calf. Parigi, 1768. & Poetry \\
\hline Capacelli (Albergati) & $\begin{array}{l}\text { II Nuovo Teatro Comico, coll'aggiunta d'alcune tragedie } \\
\text { Francesi. } 5 \text { vols. } 8 \text { vo, calf. Venezia, } 1774\end{array}$ & Theatre \\
\hline Caro (Hannibale) & Lettere Familiari. Small 4to, calf. [N. P.] 1581. & Correspondence \\
\hline Castiglione (Conte Baladesar) & $\begin{array}{l}\text { Libro de/ Cortegiano. 12mo, red morocco. Aldi Fil. [Venezia], } \\
1547 .\end{array}$ & Prose \\
\hline Contarini (Gasparo) & $\begin{array}{l}\text { Della Republica e Magistrati di Venetia. Minimo, old calf, } \\
\text { Venetia, } 1650 .\end{array}$ & Law \\
\hline Corsini (Bartolemmeo) & II Torrachione Desolato. 2 vols. Minimo. Londra, 1768. & Poetry \\
\hline Dante (Alighieri) & $\begin{array}{l}\text { La Divina Commedia con varie annotazioni e copiosi rami } \\
\text { adornata. } 5 \text { vols. 4to, vellum. Venezia, } 1757\end{array}$ & Poetry \\
\hline & II Convito e la Vita Nuova. 4 vols. 8vo, boards. Venezia, 1772. & Poetry \\
\hline Davila (Henrico Caterino) & Historia delle Guerre Civili. 2 vols. Large 4to, calf, Londra, 1755. & History \\
\hline Galileo (Galilei) & Opere. 2 vols. 4to, calf. Bologna, 1656. & Sciences \\
\hline & Opere. 4 vols. 4to, tree calf. Padova, 1744. & Sciences \\
\hline
\end{tabular}




\begin{tabular}{|c|c|c|}
\hline Garzoni (Pietro) & $\begin{array}{l}\text { Istoria della Repubblica di Venezia. Small 4to, vellum. Venezia, } \\
1720 \text {. }\end{array}$ & History of Venice \\
\hline G[C]hiabrera (Gabriello) & Opere. 6 vols. Small 8vo, tree calf. Venezia, 1782. & Poetry \\
\hline Gravina (Giovanni Vincenzo) & $\begin{array}{l}\text { Della Ragione Poetica. Libri due. I vol. Small } 8 \text { vo, calf, Napoli, } \\
\text { 1716. }\end{array}$ & Prose \\
\hline Guarini (Cavaliere) & IIPastor Fido. 12mo, calf, N. D. & Theatre \\
\hline Guicciardini & La Istoria d'Italia. 2 vols. Large fol. old calf, Venezia, 1738. & Italian history \\
\hline Guidi (Alessandro) & Poesie. 12mo, calf. Verona, 1726. & Poetry \\
\hline & $\begin{array}{l}\text { Vocabolario degli Academici della Crusca. Vols. Fol. calf. } \\
\text { Napoli, } 1746\end{array}$ & Prose \\
\hline Lipi (Lorenzo) & II Malmantile Racquistato. Minimo, calf. Parigi, 1768. & Poetry \\
\hline Macchiavelli (Nicolo) & Opere. Vols. VI. VII. and VIII. Small 8vo, calf. London, 1768 & Philosophy \\
\hline Marino (Cavaliere) & $\begin{array}{l}\text { L'Adone, Poema, el'Allegorie di Don Lorenzo Scoto. 4-to, } \\
\text { vellum. Venetia, } 1623\end{array}$ & Poetry \\
\hline & La Lira, Rime. 3 vols. Thick minimo, old calf, Venetia, 1674 & Poetry \\
\hline Metastasio (Pietro) & Poesie. 12 vols. $12 \mathrm{mo}$, old calf, Parigi, 1755 & Poetry \\
\hline Palladio (Andrea) & $\begin{array}{l}\text { Dell'Architettura. With plans and plates.) Small fol. old calf, tooled, } \\
\text { gilt edges. Venetia, } 1570\end{array}$ & Architecture \\
\hline Pallavicino (Ferrante) & L'Anima. Thick minimo, vellum. Colonia, 1675. & Philosophy \\
\hline Paolo (padre, Sarpi) & Opere. 6 vols. Small 8vo, vellum. Venetia, 1688 & Church law \\
\hline & $\begin{array}{l}\text { Parnaso Italiano ovvero Raccolto de'Poeti Classici Italiani. } 32 \\
\text { vols. Small 8vo, tree calf. Venetia, 1784-88 }\end{array}$ & Poetry \\
\hline Petrarca (Francesco) & Le Rime. Minimo, calf. Bergamo, 1752. & Poetry \\
\hline & $\begin{array}{l}\text { Le Rime brevemente esposte per Ludovico Castelvetro. } 2 \text { vols. } \\
\text { 4to, calf. Venezia, } 1756 \text {. }\end{array}$ & Poetry \\
\hline Pulci (Luigi) & IIMorgante Maggiore, 4to, vellum, Firenze, 1732 & Poetry \\
\hline $\begin{array}{l}\text { Sabellico (Marcantonio } \\
\text { Cocceio) }\end{array}$ & Istorici Veneziani. 11 vols. 4to, calf. Venezia, 1718 & History of Venice \\
\hline Sannazaro (Jacopo), & Arcadia, 1 vol., Venice, 1524 & Poetry \\
\hline Soave (Pietro) [Paolo Sarpi] & Historia del Concilio Tridentino, 4to, old calf, Geneva, 1629 & Church law \\
\hline Spallanzani (Abbate) & $\begin{array}{l}\text { Opuscoli di fisica animale e vegetabile, } 2 \text { vols, } 8 \text { vo., calf, } \\
\text { Modena, } 1786\end{array}$ & Sciences \\
\hline Tasso (Torquato) & La Gerusalemme liberata, 4 vols, 4to, calf, London, 1724 & Poetry \\
\hline Tasso (Torquato) & $\begin{array}{l}\text { La Gerusalemme liberata, } 2 \text { vols, small } 8 \text { vo, calf, Glasguae, } \\
1763\end{array}$ & Poetry \\
\hline Tassoni (Alessandro) & De' pensieri diversi, 1 vol, 4to, sheepskin, Venetia, 1676 & Philosophy \\
\hline Varchi (Benedetto) & Storia fiorentina, 1 vol, small fol. calf, Colonia, 1721 & History of Florence \\
\hline Vasari (Giorgio) & Delle vite de' pittori, 3 vols, 4to, calf, Bologna, 1647 & Biography \\
\hline
\end{tabular}




\begin{tabular}{|l|l|l|l|}
\hline & & $\begin{array}{l}\text { Venice - manuscrise pe pergament din statutele venetiene. Fara } \\
\text { pagina de titlu, denumire sau data. blazonul Venetiei, 8 vo } \\
\text { Meditazioni sulla economia politica (anon.) Nella stamperia dell' } \\
\text { Encyclopedia. con approvazione, Livorno, 1771 }\end{array}$ & Political economy \\
\hline Verri (Pietro) & $\begin{array}{l}\text { Meditazioni sulla economia sulla economia politica (anon.), 8 vo, } \\
\text { Livorno, 1772 }\end{array}$ & Political economy \\
\hline & Zeno (Apostolo) & Poesie drammatiche, 10 vols, 8 vo., calf, Venezia, 1744 & Poetry \\
\hline
\end{tabular}

